\title{
A transcriptome resource for the copepod Calanus glacialis across a range of culture temperatures
}

\author{
A.A. Ramos ${ }^{\text {a,* }}$, A. Weydmann ${ }^{\text {b,c }}$, C.J. Cox ${ }^{\text {a }}$, A.V.M. Canário ${ }^{\text {a }}$, E.A. Serrão ${ }^{\text {a }}$, G.A. Pearson ${ }^{\text {a }}$ \\ a CCMAR-Centre of Marine Sciences, University of Algarve, Campus of Gambelas, 8005-139 Faro, Portugal \\ b Institute of Oceanography, University of Gdansk, Piłsudskiego 46, 81-378 Gdynia, Poland \\ c Marine Ecology Department, Institute of Oceanology, Polish Academy of Sciences, Powstancow Warszawy 55, 81-712 Sopot, Poland
}

\section{A R T I C L E I N F O}

\section{Article history:}

Received 20 January 2015

Received in revised form 31 March 2015

Accepted 31 March 2015

Available online 8 April 2015

\section{Keywords:}

Calanus glacialis

Arctic zooplankton

454 pyrosequencing

Transcriptome

Temperature

\begin{abstract}
A B S T R A C T
The copepod Calanus glacialis plays a key role in the Arctic pelagic ecosystem. Despite its ecological importance and ongoing climate changes, limited knowledge at the genomic level has hindered the understanding of the molecular processes underlying environmental stress responses and ecological adaptation. Transcriptome data was generated from an experiment with C. glacialis copepodite (CV) subjected to five different temperatures. We obtained a total of 512,352 high-quality 454 pyrosequencing reads, which were assembled into 55,562 contigs distributed in 128 KEGG pathways. Functional analysis revealed numerous genes related to diverse biological functions and processes, including members of all major conserved signaling pathways. Comparative analysis of acclimated individuals to experimental temperatures has provided information about gene variations observed in several pathways (e.g. genes involved in energy, lipid and amino acid metabolism were shown to be down-regulated with increasing temperatures). These mRNA sequence resources will facilitate further studies on genomics and physiology-driven molecular processes in C. glacialis and related species.
\end{abstract}

(c) 2015 Elsevier B.V. All rights reserved.

\section{Introduction}

Climate change is dramatically affecting Arctic ecosystems, causing changes in oceanic circulation, sea ice loss and temperature increases that may alter marine community structure (e.g., demographic traits, spatial range, biological interactions) and ecosystem function (Post et al., 2009; Slagstad et al., 2011). The calanoid copepode Calanus glacialis plays a major role in the trophodynamics of Arctic pelagic ecosystems and is the dominant species of the genus in the northern Barents Sea (Tande, 1991). Warming of the Arctic is predicted to induce a possible replacement of $C$. glacialis by its boreal sibling Calanus finmarchicus (Reygondeau and Beaugrand, 2011; Weydmann et al., 2014a). Consequently, it is essential to understand how climate change might affect the biogeography and population dynamics of $C$. glacialis, and to predict the response and adaptability of the species to environmental fluctuations (Wassmann et al., 2011). In an effort to provide comprehensive genomic resources for $C$. glacialis and a baseline for future physiological studies, we have used Roche 454 pyrosequencing technology to characterize the temperature responsive transcriptome of this species.

\footnotetext{
* Corresponding author.

E-mail address: xramos@ualg.pt (A.A. Ramos).
}

\section{Methods and analysis}

\subsection{Sample collection and temperature experiment}

Mesozooplankton samples were collected in the Barents Sea, NE of the Hopen Island $\left(77^{\circ} 08.6^{\prime} \mathrm{N} 28^{\circ} 11.0^{\prime} \mathrm{E}\right.$; average water temperature $\left.-0.6{ }^{\circ} \mathrm{C}\right)$, with vertical tows using a WP-2 net $(0.25 \mathrm{~m}-2$ opening; $0.2 \mathrm{~mm}$ mesh size; with a large non-filtrating cod end) in June 2009. Sixty $C$. glacialis copepodites at the 5 th stage (CV) were gently picked and randomly assigned to 6 groups of 10 individuals. One of these, representing natural conditions (NAT), was immediately frozen in liquid nitrogen and stored at $-80^{\circ} \mathrm{C}$. The other 5 groups were placed in flasks $(200 \mathrm{ml})$ filled with filtered seawater and placed in a laboratory cooler (type $\mathrm{CHL} 1 \mathrm{~B}$ ) at $0{ }^{\circ} \mathrm{C}$. After $36 \mathrm{~h}$ of incubation all but one of the groups were transferred to a second cooler at $2.5^{\circ} \mathrm{C}$. This process was repeated with $2.5{ }^{\circ} \mathrm{C}$ increments every $36 \mathrm{~h}$. At the end of the experiment $(204 \mathrm{~h})$ the individuals incubated at $0{ }^{\circ} \mathrm{C}(\mathrm{T} 0), 2.5{ }^{\circ} \mathrm{C}(\mathrm{T} 2.5), 5{ }^{\circ} \mathrm{C}(\mathrm{T} 5)$, $7.5^{\circ} \mathrm{C}(\mathrm{T} 7.5)$ and $10^{\circ} \mathrm{C}(\mathrm{T} 10)$ were flash frozen in liquid nitrogen and stored at $-80^{\circ} \mathrm{C}$. See Supplementary methods for RNA preparation, cDNA synthesis and pyrosequencing.

\subsection{Bioinformatic analysis}

Sequence quality-filtering, assembly and annotation were performed essentially as described in Martins et al. (2013). An overview 
Table 1

Summary of 454 sequencing, assembly and BLASTx annotation.

\begin{tabular}{lcccc}
\hline Source & $\begin{array}{l}\text { No of raw } \\
\text { reads }\end{array}$ & $\begin{array}{l}\text { Assembled } \\
\text { quality-filtered } \\
\text { reads (\% of total) }\end{array}$ & $\begin{array}{l}\text { No. of } \\
\text { contigs }\end{array}$ & $\begin{array}{l}\text { Assembled reads with } \\
\text { BLASTx } \\
\text { (\% of total) }\end{array}$ \\
\hline Total & 721,973 & $512,352(71.0)$ & $55,562^{\mathrm{a}}$ & $324,538(67.7)$ \\
NAT & 181,118 & $134,983(74.5)$ & 14,957 & $85,963(65.1)$ \\
T0 & 169,830 & $121,663(71.6)$ & 16,297 & $80,183(67.6)$ \\
T2.5 & 59,914 & $43,080(71.9)$ & 9307 & $27,551(65.3)$ \\
T5 & 62,862 & $43,639(69.4)$ & 8860 & $27,061(63.2)$ \\
T7.5 & 111,683 & $76,266(68.3)$ & 12,661 & $47,231(63.0)$ \\
T10 & 136,566 & $92,691(67.9)$ & 13,466 & $56,549(61.9)$ \\
\hline
\end{tabular}

a Median length (N50)-620.

b E-value $\leq 1 \mathrm{e}^{-6}$.

of the sequencing and assembly results is shown in Table 1. A total of 512,352 quality-filtered reads were pooled and assembled using MIRA (v. 3.0; Chevreux et al., 2004) into 55,562 contiguous sequences (contigs) and 12,369 singletons. $41 \%$ of the assembled contigs with significant BLASTx homology (NCBI nr database, E-value $\leq 1 \mathrm{e}^{-6}$ ) were annotated against KEGG pathway and Pfam protein databases (Kanehisa and Goto, 2000; Finn et al., 2014). A total of 2733 KEGG terms were identified, mapping to 128 KEGG pathways $(22,424$ contigs). Annotation against the Pfam database identified 1691 terms (16,998 contigs). Highly represented domains, as determined by the total number of reads (>1000) mapping to the domain, were associated with cytoskeletal-related proteins and essential cell functions including energy production (glyceraldehyde 3-phosphate dehydrogenase, ATP synthase, and NADH dehydrogenase), metabolite transport (mitochondrial carrier, sugar transport and lipocalin), fatty acid biosynthesis (fatty acid desaturase), lipid catabolism (Acyl-coA dehydrogenase), cell differentiation (Ras family), protein synthesis (ribosomal genes), and signal transduction and transcription regulation (protein kinases, protein tyrosine kinases, WD40). Additionally, numerous abundant transcripts were involved in the cellular stress response; redox, antioxidant reactions and stress-related processes (cytochrome P450, glutathione S-transferase, NADH ubiquitone, thioredoxin and heat shock
proteins-HSP70, HSP90, HSP40). Several potential homologues belonging to the major conserved animal signaling pathways were also identified (e.g. Wnt, Notch, Hedgehog, TGF-, JAK-STAT and MAPK; Pires-da Silva and Sommer, 2003). Overall response to temperature of metabolic and regulatory pathways ( $R$ statistics using IDEG6, significant threshold of 0.05 , corrected for multiple tests using the False Discovery Rate, FDR $<0.1$; Romualdi et al., 2003; Stekel et al., 2000) showed different regulation mechanisms and a patchwork of up- and downregulated steps in some KEGG pathways was observed (Table 2). Furthermore, we tested a subset of simple sequence repeat (SSR) types and nine polymorphic microsatellites were suitable for population genetic studies as described in Weydmann et al., 2014b. In conclusion, we performed de novo transcriptome sequencing of $C$. glacialis incubated at increasing temperatures representing realistic warming scenarios. This pyrosequencing effort provides clues to the identification of genes potentially involved in temperature responses and generates essential molecular tools that will be useful in further genetic and genomic studies of this species.

\subsection{Data deposition}

The 454 sequence reads of $C$. glacialis were submitted to NCBI Short Read Archive (SRA) under the accession number SRP053198. The assembled transcriptome data were deposited in the European Nucleotide Archive (accession numbers HACJ01000001-HACJ01054344).

\section{Acknowledgments}

This study was supported by research grants from the European Commission 7th Framework program project ATP (Arctic Tipping Points, FP7-ENV-2008-1-226248), the Polish National Science Centre (Grant No. 2011/03/B/NZ8/02876) and the Portuguese Science and Technology Foundation (FCT) project SOPA (FCT PTDC/MAR/72630). A.R. was supported by a postdoctoral fellowship from the FCT (SFRH/ BPD/64174/2009). We would like to thank Paul Wassmann, Sławek Kwaśniewski and the crew of R/V Jan Mayen for logistic support and assistance during the experiment.

Table 2

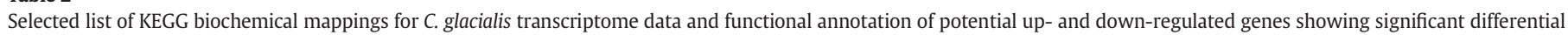
expression in the temperature experiment.

\begin{tabular}{|c|c|c|c|}
\hline KEGG pathway & Pathway ID & No of annotated enzymes & Stress regulation ${ }^{\mathrm{a}}$ \\
\hline \multicolumn{4}{|l|}{ Metabolism } \\
\hline Glycolysis/gluconeogenesis & 00010 & 18 & $\downarrow$ EC:3.1.3.11, EC:5.1.3.3 \\
\hline Citric acid cycle & 00020 & 21 & $\uparrow \mathrm{EC}: 1.2 .4 .2, \mathrm{EC}: 1.1 .1 .37$ \\
\hline Pentose phosphate pathway & 00030 & 14 & $\downarrow$ EC:2.2.1.1, EC:2.7.6.1, EC:3.1.3.11 \\
\hline Oxidative phosphorylation & 00190 & 24 & $\downarrow$ EC:1.6.5.3 U: EC:1.9.3.1, EC:3.6.3.14 \\
\hline Fatty acid elongation & 00062 & 8 & $\downarrow \mathrm{EC}: 2.3 .1 .199$ \\
\hline Fatty acid degradation & 00071 & 14 & $\begin{array}{l}\downarrow \mathrm{EC}: 1.3 .8 .8, \mathrm{EC}: 1.3 .8 .9 \\
\uparrow \mathrm{EC}: 5.3 .3 .8\end{array}$ \\
\hline Glycerolipid metabolism & 00561 & 12 & $\downarrow$ EC 2.3.1.20 \\
\hline Glyceropholipid metabolism & 00564 & 23 & $\downarrow$ EC:3.1.3.4, EC:2.3.1.23, EC:3.1.1.5 \\
\hline Biosynthesis of unsaturated fatty acids & 01040 & 7 & $\uparrow \mathrm{EC}: 2.3 .1 .199, \mathrm{EC}: 1.1 .1 .100$ \\
\hline Purine metabolism & 00230 & 40 & $\begin{array}{l}\downarrow \mathrm{EC}: 2.7 .6 .1, \mathrm{EC}: 1.7 .3 .3 \\
\uparrow \mathrm{EC}: 2.7 .4 .6\end{array}$ \\
\hline Cysteine and methionine metabolism & 00270 & 18 & $\uparrow \mathrm{EC}: 3.1 .3 .77, \mathrm{EC}: 1.13 .11 .20, \mathrm{EC}: 1.1 .1 .37$ \\
\hline Arginine and proline metabolism & 00330 & 26 & $\uparrow \mathrm{EC}: 1.5 .---, \mathrm{EC}: 1.2 .1 .88$ \\
\hline Glutathione metabolism & 00480 & 19 & $\downarrow$ EC:1.1.1.42, EC:4.1.1.17 \\
\hline \multicolumn{4}{|l|}{ Genetic information processing } \\
\hline Ribosome & 03010 & 75 & $\begin{array}{l}\downarrow \text { RP-S20e, RP-S24e, RP-S2e } \\
\uparrow \text { RP-L18e, RP-L22e, RP-L24e, RP-L29e }\end{array}$ \\
\hline RNA transport & 03013 & 29 & $\uparrow$ SMT3, EIF4E, PABPC \\
\hline Proteosome & 03050 & 9 & $\uparrow$ PSMD11, PSMA6, PSMA2, PSMA5 \\
\hline \multicolumn{4}{|l|}{ Cellular processes } \\
\hline Peroxisome & 04146 & 35 & $\downarrow:$ EC:1.17.1.4 \\
\hline
\end{tabular}

a Down $(\downarrow) /$ up- $(\uparrow)$ regulated genes with temperature increase; $p$-value $<0.05$, FDR $<0.1$; contigs with more than 20 reads and $\log _{2}$ (fold change) $>1$. 


\section{Appendix A. Supplementary data}

Supplementary data to this article can be found online at http://dx. doi.org/10.1016/j.margen.2015.03.014.

\section{References}

Chevreux, B., Pfisterer, T., Drescher, B., Driesel, A.J., Müller, W.E., Wetter, T., Suhai, S., 2004 Using the miraEST assembler for reliable and automated mRNA transcript assembly and SNP detection in sequenced ESTs. Genome Res. 14, 1147-1159.

Finn, R.D., Bateman, A., Clements, J., Coggill, P., Eberhardt, R.Y., Eddy, S.R., Heger, A. Hetherington, K., Holm, L., Mistry, J., Sonnhammer, E.L.L., Tate, J., Punta, M., 2014. The Pfam protein families database. Nucleic Acids Res. Database Issue 42, D222-D230.

Kanehisa, M., Goto, S., 2000. KEEG: Kyoto Encyclopaedia of genes and genomes. Nucleic Acids Res. 28, 27-30.

Martins, M.J., Mota, C., Pearson, G.A., 2013. Sex-biased gene expression in the brown alga Fucus vesiculosus. BMC Genomics 14, 294

Pires-da Silva, A., Sommer, R.J., 2003. The evolution of signalling pathways in animal development. Nat. Rev. Genet. 4, 39-49.

Post, E., Forchhammer, M.C., Bret-Harte, M.S., Callaghan, T.V., Christensen, T.R., Elberling B., Fox, A.D., Gilg, O., Hik, D., Høye, T.T., Ims, R.A., Jeppesen, E., Klein, D.R., Madsen, J. McGuire, A.D., Rysgaard, S., Schindler, D.E., Stirling, I., Tamstorf, M.P., Tyler, N., van der Wal, R., Welker, J., Wookey, P.A., Schmidt, N., Aastrup, P., 2009. Ecological dynamics across the arctic associated with recent climate change. Science 325, 1355-1358.
Reygondeau, G., Beaugrand, G., 2011. Future climate-driven shifts in distribution of Calanus finmarchicus. Glob. Change Biol. 17, 756-766.

Romualdi, C., Bortoluzzi, S., d'Alessi, F., Danieli, G.A., 2003. IDEG6: a web tool for detection of differentially expressed genes in multiple tag sampling experiments. Physiol. Genomics 12, 159-162.

Slagstad, D., Ellingsen, I.H., Wassmann, P., 2011. Evaluating primary and secondary production in an Arctic Ocean void of summer sea ice: an experimental simulation approach. Progr. Oceanogr. 90, 117-131.

Stekel, D.J., Git, Y., Falciani, F., 2000. The comparison of gene expression from multiple 369 cDNA libraries. Genome Res. 10, 2055-2061.

Tande, K.S., 1991. Calanus in North Norwegian fjords and in the Barents Sea. Polar Res. 10, 389-407.

Wassmann, P., Duarte, C.M., Agusti, S., Sejr, M.K., 2011. Footprints of climate change in the Arctic marine ecosystem. Global Change Biol. 17, 1235-1249.

Weydmann, A. Carstensen, J., Goszczko, I., Dmoch, K., Olszewska, A., Kwasniewski, S. 2014a. Shift towards the dominance of boreal species in the Arctic: inter-annual and spatial zooplankton variability in the West Spitsbergen. Current Mar. Ecol. Prog. Ser. 501, 41-52.

Weydmann, A., Coelho, N.C., Ramos, A.A., Serrão, E.A., Pearson, G.A., 2014b. Microsatellite marckers for the Arctic copepod Calanus glacialis and cross-amplification with C. finmarchicus. Conserv. Genet. Resour. 6, 1003-1005. 